court's jurisdiction? Such a procedure would be in full accord with the public policy to protect innocent parties who might otherwise be thrown upon the state for support. ${ }^{61}$

J.Taber.*

\title{
CORPORATIONS: LIQUIDATING DIVIDENDS BY IVASTING ASSET CORPORATIONS IN CALIFORNIA
}

\section{A. THE PROBLEM}

The production of income often involves the exhaustion of the fixed assets employed in its production. When such a decrease in value occurs as a result of the exploitation of wasting assets, ${ }^{1}$ it is referred to as depletion. Depletion differs from depreciation ${ }^{2}$ in that it is based upon the exhaustion of a natural resource, whereas depreciation is based upon the cost of exhaustion of the property used up in a trade or business. ${ }^{3}$ For illustration, assume that a merchant purchases a truck for $\$ 6,000$ which he needs in his business. The service utility of the truck is five years. The trade-in or scrap value of the truck at the end of the five-year period is $\$ 1,000$. In order to be able to purchase another truck at the end of the five-year period without utilizing other funds, the merchant will need to set aside $\$ 1,000$ a year out of earnings as a depreciation reserve.

In contrast, consider the case of a corporation engaged in the exploitation of a gold mine which cost $\$ 50,000$. The life of the mine is

61 Although resting on improper grounds, nevertheless the decision of the case could be deemed correct, judged by a literal reading of the code section governing alimony on divorce. Section 139 reads: "Where a divorce is granted for an offense of the husband...." The statute under which the foreign divorce was obtained did not adjudge either party at fault; it merely declared that the parties had been living apart for at least three years. Undoubtedly the trouble lies in the fact that section 139 never contemplated such a ground for divorce. By giving a broad or liberal interpretation to this clause, however, a subsequent hearing as to the question of alimony might be permitted. That is, it might be argued that all this clause means is that alimony is not to be awarder a wife at fault. The ecclesiastical courts would not grant alimony to a wife who had caused the divorce, and this theory predominated throughout the American courts when they came to awarding support to the wife. Therefore it would seem reasonable to conclude that the wife's innocence of marital wrong was all that was intended by the legislature in section 139 .

*Member third-year class.

1 CAL. Crv. CoDe $\$ 346$ provides that a wasting asset corporation is one which engages solely or substantially in the exploitation of mines, oil wells, gas wells, or other wasting assets of like nature; see also 11 FLETCHER, CyC. CoRps. (Perm. Ed. 1931) \$5347.

2 Hatrield, Accounting (1940) 304 ; "Depreciation may be defined as the decrease in the value of a fixed asset inevitably resulting from use, wear and tear, or passage of time in spite of repairs and maintenance." Grahasi \& Katz, dccounting IN Law PracTICE (1938) \$131; and see also \$136.

3 GRAHAM \& KATz, ibid, at $\$ \$ 131$ and 136. 
estimated to be ten years. Assume there will be no salvage value in the mine at the expiration of the ten year period. By necessity, the yearly mining operations will return a part of the capital investment. If the amount of production is the same for each year, $\$ 5,000$ of the capital investment will be depleted each year. No business man would question the necessity of subtracting the cost of an instrument of production which has been lost to the business in the gross returns in order to arrive at a net income or profit. Thus it follows that it is the generally accepted American rule that both depreciation and depletion must be taken into consideration in determining the net profit or surplus available for dividends. ${ }^{4}$ The English court in the case of Lee $v$. Neuchatel Aspralte Company ${ }^{5}$ was the first to hold that a different rule should apply regarding depletion. Subsequently, American courts have both affirmed ${ }^{6}$ and denied ${ }^{\top}$ the necessity for considering depletion.

\section{B. CAITFORNIA LAW}

Notwithstanding the statutory prohibition against impairment of capital contained in Civil Code section 309 in 1891, the California supreme court recognized a distinction between depletion and depreciation in Excelsior Water \& Mining Company v. Pierce, ${ }^{8}$ and stated that a corporation engaged in the exploitation of wasting assets need not consider depletion of such assets incidental to their exploitation in determining the amount available for dividends.

The Excelsior case involved an action by a California corporation under Civil Code section 309 against one of its former directors to recover the amount of certain dividends alleged to have been declared out of capital rather than surplus profits, and thus illegally distributed. The corporation was engaged in the hydraulic mining business. Although the court found, after properly interpreting accounting entries, that the dividends were actually paid out of surplus profits, it stated

42 Cook, Corporations, (1923 8th ed.) \$546; 7 Fletcher, Cyc. Corps. \$3658; Morawetz, Corporations (1886 2d ed.) $\$ 435$; Kirby Petroleum Company v. Com'r Internal Revenue (1946) - U.S. - , 14 L.W. 4112; Com'r Internal Revenue v. Crawford (1946) - U.S. -, 14 L.W. 4112; Whittaker v. Amwell National Bank (1894) 52 N.J. Eq. 400, 29 Atl. 203. An elaborate discussion of the theory of depreciation and a full bibliography on the subject is contained in the dissenting opinion of Mr. Justice Brandeis in United Railways and Electric Company v. West (1930) 280 U.S. 234, 255.

5 (1899) 41 Ch. D. 1; cf. Bond v. Barrow Haematite Co. (1902) 1 Ch. 353.

8 Federal Minimg \& Smelting Co. v. Wittenberg (1927) 15 Del. Ch. 409, 138 Atl. 347; see same case (1927) 15 Del. Ch. 351, 138 Atl. 352; note (1928) 55 A.L.R. 8, 43.

7 Stratton's Independence v. Howbert (1913) 231 U.S. 399 (a tax case); Excelsior water \& Mining Co. v. Pierce (1891) 90 Cal. 131, 27 Pac. 44; Van Vleet v. Evangeline Oil Co. (1911) 129 La. 406, 56 So. 343; Mellon v. Mississippi Wire Glass Co. (1910) 77 N. J. Eq. 498, 78 Atl. 710; and Boothe v. Summit Coal Mining Co. (1909) 55 Wash. 167, 104 Pac. 207.

8 (1891) 90 Cal. 131, 27 Pac. 44. 
that the statutory inhibition against division of capital stock "did not extend to the net proceeds of its mining operations; for a mining corporation, like any other corporation organized for the purpose of utilizing a wasting property - a property that can be used only by consuming it-as a mine, a lease or a patent, is not deemed to have divided its capital merely because it has distributed the net proceeds of its mining operations, although the necessary result is that so much has been subtracted from the substance of its estate," ${ }^{0}$ citing the Lee case ${ }^{10}$ and Morawetz on Corporations. ${ }^{11}$

In 1933, the California legislature included the following provision in the California corporation law: ". . . a wasting asset corporation, that is a corporation engaged solely or substantially in the exploitation of mines, oil wells, gas wells, patents or other wasting assets, or organized solely or substantially to liquidate specific assets, may distribute the net income derived from such liquidation without making any deduction or allowance for depletion of such assets incidental to the lapse of time, consumption, liquidation, or exploitation; subject, however, to adequate provision for meeting debts and liabilities and the liquidation preferences of outstanding shares and to notice to shareholders that no deduction or allowance has been made for such depletion."12

The only case in which the above section has been construed is Bailey v. Guaranty Liquidating Corporation, ${ }^{13}$ which was decided by the district court of appeal for the second district. This case involved an action by a preferred stockholder on behalf of himself and other shareholders for the purpose of enjoining the defendant corporation from paying a liquidating dividend ${ }^{14}$ on its outstanding preferred shares. ${ }^{15}$

The defendant corporation was formed for the purpose of acquiring and liquidating certain specific assets held by a bankrupt building and loan company.

The following pertinent preferences, privileges, and restrictions were contained in the articles of incorporation: (1) The holders of

9 Ibid. at 140, 27 Pac. at 46.

${ }^{10}$ Supra note 5.

11 Morawetz, Corporations (2d ed. 1886) §442.

12 CaL. Civ. Code $\$ 346$.

13 (1936) 16 Cal. App. (2d) 401, 60 P. (2d) 579. The California supreme court had previously held in Baldwin v. Miller \& Lux (1907) 152 Cal. 454, 92 Pac. 1030, prior to the adoption of Crv. CODE $\$ 346$, that a corporation specifically organized to liquidate designated assets could distribute the entire proceeds resulting from the liquidation.

14 "A liquidating dividend is not, strictly speaking, a dividend at all, that term in its general application being applied to a distribution of profits, while a liquidating dividend is a distribution of capital." 19 Fletcher, Cyc. Corps. (Perm. Ed., 1931) \$9050.

15 Plaintiff also sought to enjoin four otlier expenditures of funds by defendant corporation which are not pertinent to the problem under discussion. 
preferred shares were entitled to receive "out of any funds of the corporation at the time legally available for the declaration of dividends, dividends at the rate of six per cent per annum of the par value thereof, payable at such time or times as the board of directors may from time to time determine."16 (2) The corporation was granted the power to redeem the whole or any part of the preferred shares for cash at par value at the option of the board of directors, but no fractional shares nor any fractions of shares were to be redeemed. (3) No dividends of any nature were to be declared on common shares unless and until all outstanding preferred shares had been redeemed, or funds for that purpose had been earmarked and set aside. (4) The holders of preferred shares were granted a liquidation preference in an amount equal to their par value plus unpaid and accumulated dividends. (5) The holders of common shares were not entitled to share in liquidation distributions until the expressed preferences of the holders of the preferred shares had been satisfied.

The plaintiff contended that the declaration of the liquidating dividend on the preferred shares was illegal because the defendant corporation had no earnings and thus the distribution would result in the depletion of its assets.

The appellate court affirmed the judgment of the trial court, and held that the defendant as a liquidating corporation had power to make a ratable distribution to its preferred shareholders from the proceeds resulting from the liquidation of its assets, other than the six per cent authorized in the articles, even though the distribution, of necessity, resulted in the depletion of its capital, citing Baldwin $v$. Miller $\mathcal{E}$ Lux, ${ }^{17}$ and Civil Code section 346.

The court stated "that there is no allegation in appellant's coinplaint or in the fourth cause of action thereof that any dividend will or has been paid in pursuance to such charter provision. That the corporation has authority to declare a liquidating dividend is settled by authority ...."18 (italics supplied).

Section 346, insofar as it applies to liquidating corporations, incorporated the rule of the Baldwin case that a corporation organized to liquidate certain specified assets could distribute the net proceeds resulting from their liquidation, and for the first time, gave legislative sanction to that rule.

The effect of the last paragraph of section 346 is to excuse charges for depletion in determining the amount available for dividends in wasting asset corporations, subject to adequate provision for protect- 
ing the prior rights of creditors and preferred shareholders. Creditors were not involved in the principal case. Nor were the rights of the preferred shareholders endangered by the declaration of the liquidating distribution contemplated by the corporation.

It should be observed, however, that the section does not authorize the distribution of the proceeds derived from liquidation to shareholders to any greater extent than that provided for by the articles of incorporation. The rights of the preferred shareholders as to dividends and liquidations are governed by the preferred share contract in the articles. ${ }^{13}$

There is no provision in section 346 for paying liquidating dividends upon preferred shares except as called for in the charter contract. Payments on preferred shares may be made only (1) by way of the specified preferred dividends; (2) by redemption or purchase under Civil Code section 342, out of surplus or capital; (3) under Civil Code section $348 \mathrm{~b}(2)$ out of reduction surplus; or (4) under Civil Code section 401a in connection with dissolution and winding up.

The last is the only authority for making distributions of capital in installments from time to time on preferred shares. To make such payments on preferred shares in partial retirement while the corporation is a going concern is not authorized and would also endanger innocent purchasers of certificates which did not show that the shares had been partially retired. Section 346 does not authorize partial liquidating dividends on preferred shares by way of gradual retirement or redemption. ${ }^{20}$

Assume that a wasting asset corporation issues both preferred and common stock, and that the preferred stock is granted a liquidation preference. Suppose the corporation has consistently declared dividends on both kinds of stock out of net proceeds without establishing a fund to take care of the liquidation preferences of the preferred shareholders, and there are not sufficient assets left to meet this preference. Has the provision of Civil Code section 346 which requires that "adequate provision for meeting debts and liabilities and the liquidation preferences of outstanding shares" been violated? It would seem so. In order to make adequate provision for that preference it is submitted that sufficient funds should be accumulated with a responsible bank, either as a trust or sinking fund to cover the amount of the preference.

C. STATUTES AT LARGE

Seventeen states have adopted provisions of the same general

196 Fletcher, Cyc. Corps. (Perm. Ed. 1931) §2487; 6A Calif. JurIS. (1932) §744.

20 Supra note 12. 
nature of the California Civil Code section $346 .{ }^{21}$ These statutes fall into two general classes: (1) Those jurisdictions that require an affirmative provision in the articles of incorporation; ${ }^{22}$ (2) those jurisdictions where the statutes are of general application. ${ }^{23}$

Limited safeguards are provided by a few of the statutes. "Adequate provision" must be made in California and Minnesota to meet the obligations to creditors and preferences of shareholders of different classes, including notice to shareholders that dividends have been declared without making allowance for depletion. ${ }^{24}$ Pennsylvania and Washington require the corporation to protect "the rights of the shareholders of different classes." ${ }^{325}$ But the majority of states impose no special safeguards. ${ }^{26}$

Of the jurisdictions which require the articles of incorporation to contain such a provision in order to exempt depletion, the Indiana statute provides that dividends may only be declared "subject to the rights of creditors and shareholders of different classes." 27 The statutes of Louisiana ${ }^{28}$ and Ohio $^{29}$ only mention the rights of the shareholders of different classes. Georgia makes no special provision. ${ }^{30}$

It is all too evident from the majority of these statutes that, except insofar as protection may be given by other statutory provisions prohibiting the payment of dividends while the corporation is insolvent, or which will render it insolvent, little protection is afforded by these statutes to the rights of creditors or shareholders with liquidation preferences.

21 Arkansas, 1 Ark Dig. Stat. (Pope, 1937) c. 37, §2183; California, Cax. Crv. Code \$346; Delaware, Dez. Rev. Code (1935) c. 65, \$34; Georgia, Corporation Act of 1938, Corporations Charters \$16; Idaho, 2 IDABo Code ANN. (1932) \$29-129; Indiana, 6 IND. Ann. Stat. (Burns. 1933) \$25-211; Kansas, Kan. Gen. Stat. Supp. (1943) \$17-3503; Louisiana, 1 LA. Gen. Stat. ANn. (Dart, 1939) $\$ \$ 1082$ and 1106 ; Maine, Me. Rev. Stat. (1930) c. 56, §118; Michigan, Public and Local Acts (1943) Act No. 160, \$21.22; Minnesota, Minn. Stat. (Mason, Supp. 1938) \$7492-21; Montana, Laws of Montana (1943) c. 141, \$5939; Nebraska, Gen. Corp. Law (1941) c. 41, \$35; Ohio, OHro Ann. Code (Throckmorton, 1940) §8623-38; Pennsylvania, Pa. Stat. (Purdon, Compact ed. 1936) Lit. 15, §2852-701; Washington, 5 WASH. REv. Stat. ANN. (Remington, 1940) §3803-24 (7); and West Virgima, 1 W. VA. Code ANN. (1943; \$3082.

22 Georgia, Indiana, Louisiana, and Ohio.

23 Arkansas, California, Delaware, Indiana, Kansas, Maine, Michigan, Minnesota, Montana, Nebraska, Pennsylvania, Washmgtor, and West Virginia.

24 Supra note 21.

25 loid.

26 Arkansas, Delaware, Georgia, Idaho, Kansas, Maine, Michigan, Montana, Nehraska, and West Virginia.

27 Supra note 21.

28 Ibid.

29 Ibid.

30 Ibid. 


\section{POLICY}

What are the reasons which have given rise to the adoption of the rule excepting wasting asset corporations from considering depletion in determining surplus available for dividends? The exact policy supporting the rule has never been clearly stated, ${ }^{31}$ which in itself is indicative of its unsoundness. The justification for the doctrine, viewed from the aspect of business practice, is said to lie in the nature of wasting asset corporations. It is reported to be a matter of common knowledge to investors and creditors alike that such corporations are primarily speculative in nature, and not formed for long term investment purposes..$^{32}$ Victor Morawetz, who first suggested that wasting asset corporations should be allowed to disregard depletion, stated that "... It is implied from the character of the speculation of a mining company, that the income derived from working the mine shall be distributed among the shareholders as dividends, after deducting expenses, and making reasonable provisions for contingencies." Morawetz, however, limited the application of the doctrine "to a corporation whose sole purpose is to invest its capital in a specific piece of property, like a mine, and afterward to consume the property or extract its value at a profit." 33 (Italics supplied).

The proponents of the doctrine advance the argument that the rule is supported by business practice, insisting that the purchaser of stock in a wasting asset corporation, such as a mining concern, is not interested in having the company retain the investment intact, which of necessity, must either lie dormant in the treasury or be reinvested; that he is aware that when the wasting asset has been exhausted the stock is no longer of any value. It is said that because of the nature of such a business, creditors secure the protection needed by contractual arrangements, and, as a matter of business custom, seldom extend long term credit.

The critics of the doctrine emphasize the following shortcomings: $:^{34}$ (1) The burden of securing protection is improperly allocated, in that creditors and preferred shareholders should be afforded ade.

31 Ballantine and Hills, Corporate Capital and Dividend Restriclions (1935) 23 Calif. L. Rev. 229, 249.

32 Note (1926) 12 CoRneLl L.Q. 79, 83.

33 Morawetz, Corporations (2d. 1886) \$442.

34 Dodd \& Baker, Cases on Business Assoctations, Note, Statutes Relating to Wasting Assets and Depletion (1940) 1102; Palmer, Conrpany Precedents (15th ed. 1938) 720; Reiter, Profits, Divmends aNd the Law (1926) 44, 140; HatField, ACcovstrng (1927) 264 ; Ballantine and Hills, Corporate Capital and Dividend Reshrictions (1935) 23 CaLIF. L. Rev. 229, 249; Gold, lixed and Circulaling Capital in the knglish Law of Dividends (1945) 6 U. OE Toronto L.J. 14; Wemer, Theory of Anglo-American Dividend Law: American Statutes and Cases (1929) 29 Cor. L. Rev. 461, 477; note (1936) 43 W. VA. L.Q. 53. 
quate protection as a matter of law, rather than mere reliance upon self-imposed safeguards. (2) There is no fundamental difference between depreciation and depletion when applied to corporations engaged in the continuous exploitation of wasting assets which justifies the application of different rules in determining the assets available for the declaration of dividends. (3) No valid reasons have been advanced by the courts supporting the doctrine which warrant the relaxation of normal capital safeguards afforded to creditors and preferred shareholders. (4) Where shareholders are granted liquidation preferences, the periodic distribution of proceeds, without deduction for depletion, is actually a partial return of the investment. This impairs the liquidation preference until the point is reached where the preference is defeated. (5) Further, it is pointed out that corporations engaged in a continuous business involving wasting assets actually take depletion into consideration as a matter of normal accounting and sound business practice. ${ }^{35}(6)$ Finally, such corporations are economically compelled to maintain accurate accounting of depletion in order to benefit from the statutory deductions allowed for depletion by the Internal Revenue $\operatorname{Code}^{36}$ in determining profits subject to federal ir come taxation.

It might be conceded, however, that a corporation organized to exploit and distribute the proceeds of a particular mine or other property may properly be excused from making any reserve for depletion except for the protection of creditors and senior shareholders.

\section{E. RECOMMENDATIONS}

It would appear that the provisions of section 346, insofar as it refers to wasting asset corporations, permit of abuses which should be regulated. To exclude the possibility of the occurrence of such abuses, it is advocated that the section be amended to provide:

“346. Cash or property dividends: (Declaration: When permissible: Wasting asset corporations).

Wasting asset corpoxation. A wasting asset corporation, that is a corporation, the declared corporate purpose of which is to engage solely or principally in the exploitation of specific mines, oil wells, gas wells, patents or other specific wasting assets, or organized solely or principally to liquidate specific assets described in the articles of incorporation, may distribute the net proceeds derived from the exploitation of such wasting assets or the net proceeds derived from such liquidation without making any deduction or allowance for the 